\title{
Effects of Targeted Replacement of the Tomatinase Gene on the Interaction of Septoria lycopersici with Tomato Plants
}

\author{
A. M. Martin-Hernandez, M. Dufresne, V. Hugouvieux, R. Melton, and A. Osbourn \\ The Sainsbury Laboratory, John Innes Centre, Norwich Research Park, Norwich NR4 7UH, U.K. \\ Accepted 10 August 2000.
}

\begin{abstract}
Many plants produce constitutive antifungal molecules belonging to the saponin family of secondary metabolites, which have been implicated in plant defense. Successful pathogens of these plants must presumably have some means of combating the chemical defenses of their hosts. In the oat root pathogen Gaeumannomyces graminis, the saponin-detoxifying enzyme avenacinase has been shown to be essential for pathogenicity. A number of other phytopathogenic fungi also produce saponin-degrading enzymes, although the significance of these for saponin resistance and pathogenicity has not yet been established. The tomato leaf spot pathogen Septoria lycopersici secretes the enzyme tomatinase, which degrades the tomato steroidal glycoalkaloid $\alpha$-tomatine. Here we report the isolation and characterization of tomatinase-deficient mutants of $S$. $l y$ copersici following targeted gene disruption. Tomatinaseminus mutants were more sensitive to $\alpha$-tomatine than the wild-type strain. They could, however, still grow in the presence of $1 \mathrm{mM} \alpha$-tomatine, suggesting that nondegradative mechanisms of tolerance are also important. There were no obvious effects of loss of tomatinase on macroscopic lesion formation on tomato leaves, but trypan blue staining of infected tissue during the early stages of infection revealed more dying mesophyll cells in leaves that had been inoculated with tomatinase-minus mutants. Expression of a defense-related basic $\beta-1,3$ glucanase gene was also enhanced in these leaves. These differences in plant response may be associated with subtle differences in the growth of the wild-type and mutant strains during infection. Alternatively, tomatinase may be involved in suppression of plant defense mechanisms.
\end{abstract}

Additional keywords: Lycopersicon, phytoanticipin, phytoprotectant.

Many plant species synthesize molecules that belong to the class of secondary metabolites known as saponins (Hostettmann and Marston 1995; Price et al. 1987). Saponins are glycosylated triterpenoids, steroids, or steroidal alkaloids that often have potent broad-spectrum antifungal activity and

Corresponding author: A. Osbourn; E-mail: annie.osbourn@bbsrc.ac.uk

Current address of V. Hugouvieux: Department of Biology, University of California San Diego, La Jolla, CA 92093-0116, U.S.A. are found constitutively in healthy plants in the absence of challenging pathogens (in contrast to phytoalexins, which are synthesized in response to pathogen attack or stress as part of the plant defense response). These preformed secondary metabolites have therefore been implicated as antimicrobial phytoprotectants that protect plants against attack by a wide range of potential pathogens (Fenwick et al. 1992; Morrissey and Osbourn 1999; Osbourn 1996; Schönbeck and Schlösser 1976). This premise has been supported by the demonstration that oat mutants deficient in the ability to synthesize triterpenoid root saponins (avenacins) are compromised in resistance to a variety of fungal pathogens (Papadopoulou et al. 1999).

In vitro growth tests indicate that successful pathogens of saponin-producing plants often are more tolerant of their respective host plant saponins when compared with nonpathogens of these plants (Arneson and Durbin 1968b; Carter et al. 1999; Crombie et al. 1986; Lüning and Schlösser 1976; Osbourn 1999; Osbourn et al 1991; Sandrock and VanEtten 1998; Steel and Drysdale 1988; Suleman et al. 1996; Turner 1961). These findings suggest that saponin resistance is important for host colonization. Enzymatic degradation represents one mechanism for combating the antifungal effects of saponins; evidence for the significance of saponin detoxification has emerged from studies with the root-infecting fungus Gaeumannomyces graminis, which causes "take-all" disease of cereals. Oat-attacking isolates of G. graminis produce the saponin-detoxifying enzyme avenacinase, which hydrolyzes terminal D-glucose molecules from the triterpenoid oat root saponin avenacin A-1 (Crombie et al. 1986; Osbourn et al. 1991; Turner 1961). Avenacin A-1 is localized in the epidermal cell layer of oat roots (Osbourn et al. 1994), and since $G$. graminis infects roots by direct penetration of this cell layer, the invading hyphal tips are likely to encounter substantial amounts of this saponin. Avenacinase-deficient mutants of $G$. graminis var. avenae that are unable to degrade avenacin A-1 have been generated by targeted gene disruption. Significantly, these mutants were unable to penetrate oat roots and were no longer pathogenic to oats, demonstrating that, at least in this interaction, saponin detoxification is essential for pathogenicity (Bowyer et al. 1995).

There are a number of other reports of degradation of saponins by fungi, in particular for pathogens of solanaceous plants. Most solanaceous plants, including the major food crops tomato (Lycopersicon esculentum) and potato (Solanum tuberosum) produce steroidal glycoalkaloid saponins. In $L y$ - 
copersicon species, the major steroidal glycoalkaloid is $\alpha$ tomatine (Fig. 1) (Roddick 1974). $\alpha$-Tomatine has potent antimicrobial activity and may attain concentrations as high as 1 $\mathrm{mM}$ in healthy tomato leaf tissue (Arneson and Durbin 1968a), levels that are more than adequate to inhibit the growth of many fungi in vitro (Arneson and Durbin 1968a; Sandrock and VanEtten 1998). The tetrasaccharide chain attached to the carbon 3 molecule of $\alpha$-tomatine is critical for antifungal activity, and removal of even a single sugar results in a substantial reduction in toxicity (Arneson and Durbin 1968a; Keukens et al. 1992; Keukens et al. 1995; Sandrock and VanEtten 1998). The tomato pathogens Septoria lycopersici (Arneson and Durbin 1967; Durbin and Uchytil 1969), Botrytis cinerea (Quidde et al. 1998; Urbasch 1986; Verhoeff and Liem 1975), Fusarium oxysporum f. sp. lycopersici (Ford et al. 1977; Lairini et al. 1996; Roldán-Arjona et al. 1999), Verticillium albo-atrum (Pegg and Woodward 1986), and Alternaria solani (Schönbeck and Schlösser 1976) all produce extracellular enzymes that hydrolyze sugars from $\alpha$-tomatine in various ways (known collectively as tomatinases) (Fig. 1) (reviewed in Morrissey and Osbourn 1999). The significance of $\alpha$-tomatine degradation for $\alpha$-tomatine resistance and pathogenicity, however, has not yet been established for any of these fungi.

The work described here concerns the tomatinase enzyme produced by the tomato leaf spot pathogen $S$. lycopersici. This enzyme hydrolyzes the terminal $\beta$-1,2-linked D-glucose molecule from $\alpha$-tomatine to give $\beta_{2}$-tomatine (Fig. 1) (Arneson and Durbin 1967; Durbin and Uchytil 1969; Osbourn et al. 1995; Sandrock et al. 1995). Degradation of avenacin A-1 by the $G$. graminis avenacinase enzyme also involves hydrolysis of a terminal $\beta$-1,2-linked D-glucose molecule, although $S$. lycopersici tomatinase and $G$. graminis avenacinase clearly differ in their substrate specificities (Osbourn et al. 1995). The isolation and characterization of the genes encoding these two enzymes have established that they belong to the same family of $\beta$-glucosyl hydrolases (Osbourn et al. 1995; Sandrock et al. 1995), and hence taxonomically remote fungi may employ common degradative strategies to combat the saponins of their host plants (Osbourn et al. 1995). Very little is known about the way in which $S$. lycopersici infects tomato leaves or about the significance of $\alpha$-tomatine degradation for this process.
Here we investigate the importance of tomatinase for $\alpha$ tomatine resistance and pathogenicity by isolating tomatinasedeficient mutants of $S$. lycopersici using targeted gene disruption.

\section{RESULTS}

\section{Targeted disruption of the tomatinase gene.}

Southern blot analysis of genomic DNA of S. lycopersici, digested separately with four different restriction enzymes (ClaI, EcoRV, BamHI, EcoRI) and probed with a polymerase chain reaction (PCR) fragment generated from the tomatinase cDNA clone pCTOM6 (Osbourn et al. 1995) using primers 1 and 2 (Fig. 2), confirmed the presence of a single tomatinase gene in the wild-type strain NEV (data not shown). A genomic clone containing the complete tomatinase gene plus flanking DNA for use in the construction of a vector for targeted gene replacement was isolated as follows. A genomic DNA library for the S. lycopersici strain NEV was constructed in the bacteriophage vector lambda ZAP II and screened with the tomatinase cDNA probe. Positive plaques were purified through three rounds and the resulting phage analyzed directly by PCR. The pBluescript II T3 and T7 primers were used in combination with primers designed to amplify outward from the $5^{\prime}$ and $3^{\prime}$ ends of the tomatinase gene (primers $5^{\prime}$ tom and $3^{\prime}$ tom; experimental procedures) to identify those plaques containing the gene plus as much flanking DNA as possible to facilitate gene replacement by homologous recombination. This resulted in the identification of the clone pGTOM1, which contains the full-length tomatinase gene plus an additional 1.6 and $2.1 \mathrm{~kb}$ of flanking DNA at the $5^{\prime}$ and $3^{\prime}$ ends, respectively (Fig. 2).

The gene replacement vector pGTOMD was constructed from pGTOM1 as shown in Figure 2. pGTOMD was linearized with NotI, which cuts once within the vector DNA, and introduced into $S$. lycopersici strain NEV by PEG-mediated protoplast transformation with selection on medium containing hygromycin B. A total of 650 hygromycin-resistant regenerants were then purified by three successive rounds of mycelial subculture on selective medium. All 650 regenerants were screened by PCR using the primers shown in Figure 2. Primers 4 and 5 were used to amplify a 712-bp PCR product con-

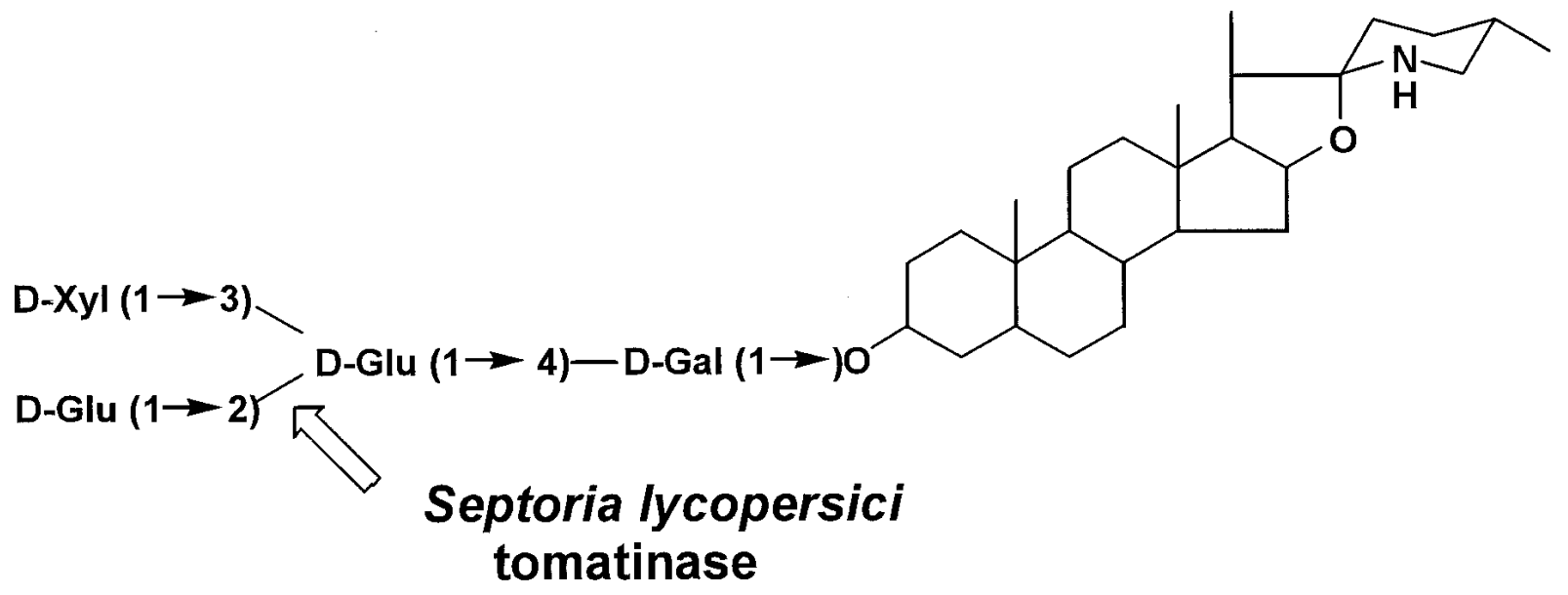

Fig. 1. Degradation of the steroidal glycoalkaloid $\alpha$-tomatine to $\beta_{2}$-tomatine by Septoria lycopersici tomatinase. 
taining the $h p h$ cassette. Primers 1 and 3 gave a 1.3-kb PCR product with the intact tomatinase gene but failed to amplify if gene replacement had occurred. A number of candidate gene replacement mutants were identified using these primer pairs. Gene disruption was then confirmed by Southern blot analysis (examples of the hybridization patterns observed with the wild-type and transformed strains are shown in Figure 3). BamH1-digested genomic DNA of the wild-type strain gave two hybridizing restriction fragments of 1.9 and $2.4 \mathrm{~kb}$ when probed with a tomatinase cDNA probe (Fig. 3, lane 1). Transformants that had undergone replacement of the tomatinase gene and therefore lost the internal Bam $\mathrm{H} 1$ site yielded a single band of $5.5 \mathrm{~kb}$ (e.g., transformant 20D2, Fig. 3, lane 2). Ectopic transformants contained the 1.9- and 2.4-kb fragments in common with the wild type, plus one or more additional bands of various sizes (e.g., transformant 2B4, Fig. 3, lane 3). Five gene replacement mutants with the expected hybridization pattern were identified from the 650 hygromycin-resistant regenerants originally isolated.

\section{Analysis of tomatinase activity and $\alpha$-tomatine resistance of transformants.}

Loss of tomatinase activity in the gene replacement mutants was confirmed by growing the wild-type strain NEV, two ectopic transformants (2B4 and 2E3), and the five gene replacement mutants (2D2, 20D2, 19D1, 19D5, and 21B3) in liquid culture under standard conditions for tomatinase production and assaying ammonium sulfate-concentrated culture filtrates for the ability to hydrolyze glucose from $\alpha$-tomatine, as described in Osbourn et al. (1995). There were no obvious differences in the ability of the strains to grow in liquid culture. Tomatinase activity was readily detectable in protein preparations derived from the wild-type strain and the ectopic transformants. Specific activities for these strains ranged from 22 to $98 \mu \mathrm{g}$ of glucose released/ $\mu \mathrm{g}$ of protein/h in four separate experiments. Differences in specific activities were the result of experimental variation, and there was no effect of ectopic insertions on tomatinase activity when values for the ectopic transformants and wild-type strain were compared (data not shown). Tomatinase activity was not detected when ammonium sulfate-concentrated culture filtrates of the five gene replacement mutants were assayed using amounts of protein that were comparable to those used for the wild-type strain and ectopic transformants. Thus, mutation of the tomatinase gene results in absence of detectable levels of tomatinase activity in vitro under the growth conditions used in these experiments.

The five tomatinase-minus mutants (2D2, 20D2, 19D1, 19D5, and 21B3) were compared with the wild-type strain and five ectopic transformants (2B4, 2E3, 11D2, 9A1, and 14E5) for their ability to grow in the presence of $\alpha$-tomatine (representative results are given in Table 1). The wild-type strain and ectopic transformants showed little or no inhibition of growth on Czapek Dox V8 agar containing $50 \mu \mathrm{M} \alpha$ tomatine, with inhibition increasing to around $20 \%$ at $1 \mathrm{mM}$ $\alpha$-tomatine. In contrast, tomatinase-minus mutants showed a $50 \%$ reduction in growth at $50 \mu \mathrm{M} \alpha$-tomatine and approximately 55 to $60 \%$ inhibition at levels between $100 \mu \mathrm{M}$ and $1 \mathrm{mM}$. The growth of the tomatinase-minus strains in the absence of the steroidal glycoalkaloid was comparable to that of the wild type. Similar results were obtained when complete medium (CM) agar was used (data not shown). Subsequent experiments on Czapek Dox V8 agar containing lower levels of $\alpha$-tomatine revealed that concentrations of 10,25 , and $50 \mu \mathrm{M}$ had no significant effect on the growth of the wild-type strain or the two ectopic transformants (2B4 and 2E3) that were included as controls. The growth of the tomatinaseminus mutant (2D2) included in the experiment was not affected at the lowest $\alpha$-tomatine concentration $(10 \mu \mathrm{M})$, but about 30 and $46 \%$ inhibition in growth of this strain was observed at concentrations of 25 and $50 \mu \mathrm{M} \alpha$-tomatine, respectively (data not shown).

\section{Pathogenicity to Lycopersicon spp.}

The tomatinase-minus mutants 2D2 and 20D2 were tested along with the wild-type strain NEV and an ectopic transfor-
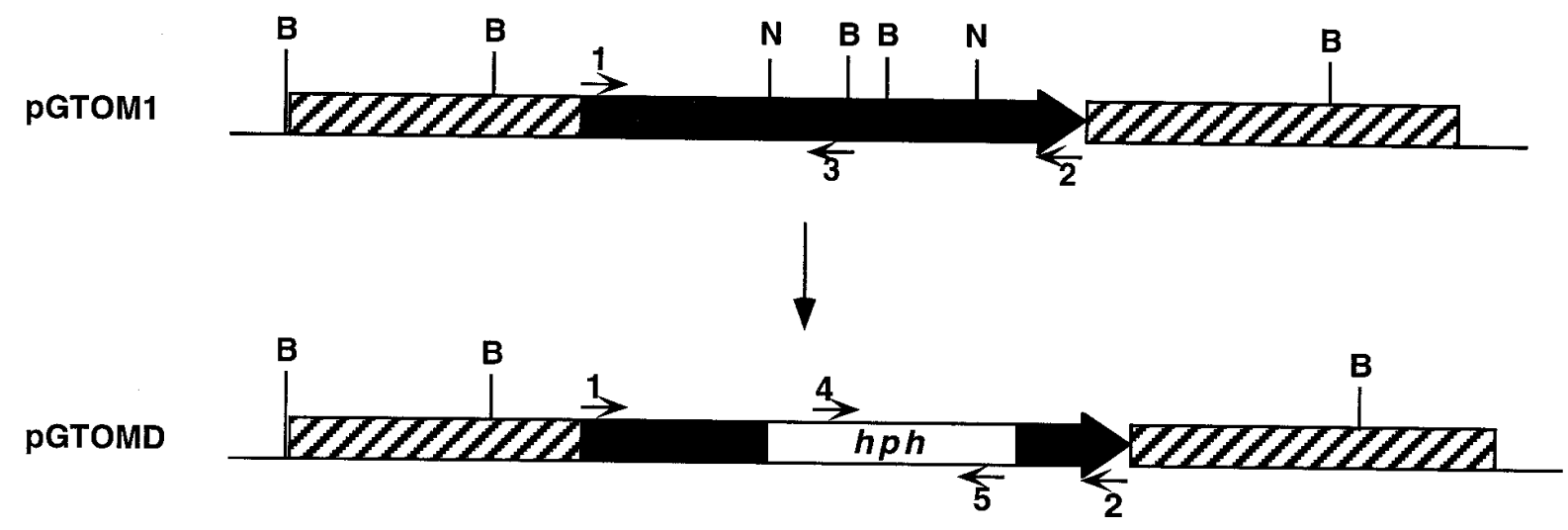

$1 \mathrm{~Kb}$

Fig. 2. Construction of a plasmid for targeted disruption of the tomatinase gene. The plasmid pGTOM1 was isolated from a phagemid library of genomic DNA of Septoria lycopersici strain NEV and contains the complete tomatinase gene (represented by the black arrow) and flanking genomic DNA sequences (striped boxes). The gene replacement construct pGTOMD was generated from pGTOM1 by replacement of the 1.1-kb NdeI restriction fragment internal to the tomatinase gene with the hygromycin phosphotransferase cassette $(h p h)$ from pCB 1004 . The annealing sites of primers used for the molecular characterization of transformants are indicated by the numbered arrows. $\mathrm{N}=$ Nde $\mathrm{I} ; \mathrm{B}=$ Bam $\mathrm{H} 1$. 
mant (2B4) for the ability to cause disease on detached leaves of L. pimpinellifolium accessions 1248 and 1335. These accessions are reported to contain moderate and high levels of $\alpha$-tomatine, respectively (Juvik et al. 1982). Numerous large

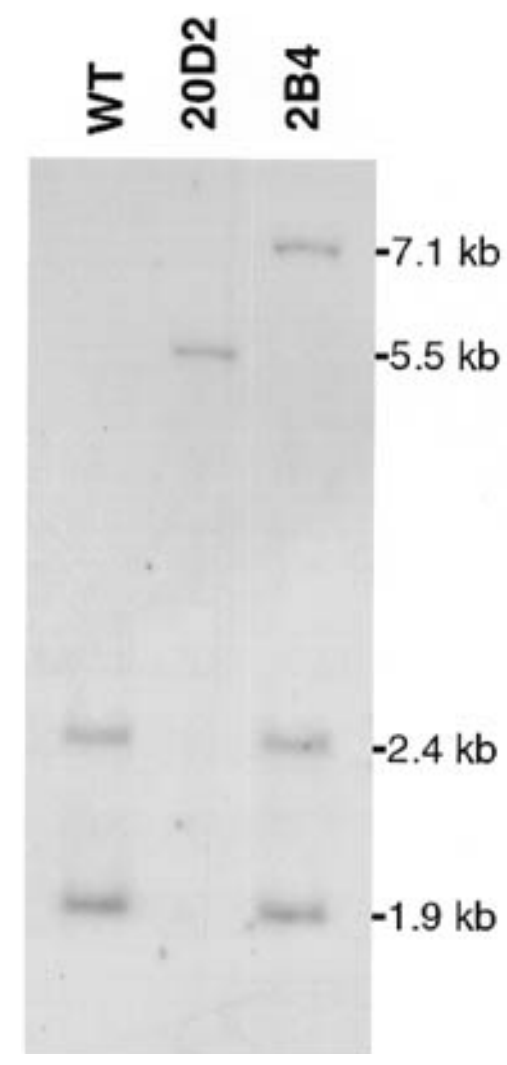

Fig. 3. Southern blot analysis of transformants. BamH1-digested genomic DNA was transferred to Hybond $\mathrm{N}$ membrane and probed with a digoxigenin-labeled tomatinase cDNA probe. WT, wild-type strain NEV; 20D2, transformant that has undergone replacement of the tomatinase gene; $2 \mathrm{~B} 4$, ectopic transformant.

Table 1. Growth of wild-type and tomatinase-deficient Septoria lycopersici strains on $\alpha$-tomatine

\begin{tabular}{lrcc}
\hline Strain & $\begin{array}{c}\alpha \text {-tomatine } \\
(\boldsymbol{\mu M})\end{array}$ & Growth $^{\mathbf{a}}(\mathbf{c m})$ & $\begin{array}{c}\text { Growth } \\
\text { inhibition }(\boldsymbol{\%})\end{array}$ \\
\hline Wild type & 0 & $1.66 \pm 0.07$ & 0 \\
& 50 & $1.65 \pm 0.05$ & 1 \\
& 100 & $1.45 \pm 0.07$ & 13 \\
& 500 & $1.45 \pm 0.06$ & 13 \\
2E3 (ectopic) & 1,000 & $1.30 \pm 0.06$ & 22 \\
& 0 & $1.53 \pm 0.08$ & 0 \\
& 50 & $1.49 \pm 0.07$ & 4 \\
& 100 & $1.32 \pm 0.02$ & 14 \\
2D2 (tomatinase- & 500 & $1.16 \pm 0.10$ & 24 \\
minus mutant) & 1,000 & $1.22 \pm 0.06$ & 20 \\
& 0 & $1.75 \pm 0.06$ & 0 \\
& & & \\
& 50 & $0.88 \pm 0.05$ & 50 \\
& 100 & $0.74 \pm 0.04$ & 58 \\
& 500 & $0.76 \pm 0.04$ & 57 \\
& 1,000 & $0.77 \pm 0.02$ & 56
\end{tabular}

a Values represent increase in colony diameter on Czapek Dox V8 agar over an 8-day period once young colonies were established (8 to 16 days following inoculation). Values are means \pm standard deviations derived from measurement of five independent colonies. spreading lesions developed on leaves of LA 1248 following inoculation, but there were no discernible differences in the extent and rate of symptom development when the wild-type strain, the ectopic transformant, and the tomatinase-minus mutants were compared (Fig. 4, upper panels). Fewer, smaller lesions developed on leaves of LA 1335 when challenged with these various fungal strains, but again there were no obvious differences between the tomatinase-producing and nonproducing strains (Fig. 4, lower panels). L. esculentum cv. Moneymaker $(C f O)$ produced results that were comparable to those obtained with LA 1335 (not shown). These pathogenicity assays were repeated twice more with similar outcomes.

\section{Analysis of the fungal infection process and plant defense responses.}

S. lycopersici has been reported to infect tomato leaves primarily via stomata but also by direct penetration of epidermal cells (Perelló et al. 1991; Sohi and Sokhi 1973). The way in which the fungus grows within the leaf tissue has not been described. Cytological analysis was carried out to investigate the fungal infection process and to compare the behavior of the wild-type and mutant strains.

Preliminary experiments to investigate the infection process involved inoculation of detached leaves of L. pimpinellifolium accession 1248 with the wild-type $S$. lycopersici strain NEV. Leaves were stained with lactophenol/trypan blue at different times following inoculation and examined under bright-field illumination. Germ tubes infected leaves through the stomata (Fig. 5A), and direct penetration of epidermal cells was not observed under our assay conditions. Multiple penetrations of individual stoma by different germ tubes were also seen, providing additional evidence for stomatal penetration as the chief infection route. Macroscopic lesions were visible 6 to 8 days after inoculation. Fungal growth was difficult to visualize in these regions because of the numerous trypan bluestained (dying) and brown necrotic plant cells at the centers of the lesions (not shown). At the margins of developing lesions, the fungus grew intercellularly within the mesophyll, forming V-shaped branches around the plant cells (Fig. 5B). There were very few necrotic host cells in these areas, suggesting that colonization of the surrounding tissue may initially be biotrophic.

Detached leaves of L. pimpinellifolium accessions LA 1248 and LA 1335 that had been inoculated with the wild-type strain, ectopic transformants, or tomatinase-minus mutants were then examined immediately after inoculation and after 2, 4,6 , and 8 days of incubation. For LA 1248, there were no obvious differences in the extent and nature of fungal growth within the plant tissue for the tomatinase-producing and nonproducing strains, and thick branching hyphae were readily visualized within the leaf mesophyll for all strains (Fig. 5B). For LA 1335, fungal colonization was less extensive (consistent with this accession showing only limited lesion development) and mycelial colonization was less vigorous (thinner hyphae with less branching), but again the tomatinase-producing and nonproducing strains were indistinguishable (not shown). However, when leaves of both accessions were stained with trypan blue 2 to 4 days after inoculation, staining was consistently more intense in leaves that had been inoculated with the tomatinase-minus strains when compared 
with those inoculated with the control strains (e.g., Fig. 6A), indicating that more host cells were dying. Northern blot analysis with leaves of L. pimpinellifolium LA 1248 revealed that expression of a defense-related gene encoding a basic $\beta$ 1,3 glucanase (van Kan et al. 1992) was enhanced in leaves inoculated with the tomatinase-minus mutant (Fig. 6B). Very similar results were seen when the Northern blot analysis was repeated with RNA from an independent infection experiment.

Assays of $\alpha$-tomatine-degrading activity in infected leaves.

Since colonization of leaves of Lycopersicon spp. by $S$. lycopersici initially involves intercellular growth and most fungal saponin detoxifying enzymes (including $S$. lycopersici tomatinase) are secreted (Morrissey and Osbourn 1999), we analyzed apoplastic fluids of infected leaves of L. pimpinellifolium accession 1248 and Moneymaker $C f O$ for the ability to hydrolyze D-glucose from $\alpha$-tomatine and also for other $\alpha$ tomatine-degrading activities. Inoculated leaves were harvested $1,3,5,7$, and 10 days after inoculation and vacuuminfiltrated with water. Intercellular fluids were recovered by centrifugation using methods similar to those developed for analysis of Cladosporium fulvum-tomato interactions (DeWit and Spikman 1982). Following lyophilization and resuspension, the preparations were assayed for the ability to release glucose from $\alpha$-tomatine. Tomatinase activity, as assessed by hydrolysis of D-glucose from $\alpha$-tomatine, could readily be detected in preparations from leaves of $L$. piminellifolium accession 1248 inoculated with $S$. lycopersici strain NEV from 5 days postinoculation onward and for Moneymaker $C f O$ at 10 days. Thin-layer chromatography (TLC) analysis confirmed that $\beta_{2}$-tomatine was the only hydrolysis product (Fig. 7). The amounts of intercellular fluid recovered from 20D2inoculated and mock-inoculated leaves were generally comparable to those recovered from NEV-inoculated leaves and were never less than $50 \%$ of volumes recovered for the wild type. However, these apoplastic preparations did not generate $\beta_{2}$-tomatine or any other hydrolysis products of $\alpha$-tomatine, even after prolonged incubation (Fig. 7).

\section{DISCUSSION}

The young leaves of tomato plants are rich in $\alpha$-tomatine (Roddick 1974). Fungi that are able to invade tomato leaf tissue must presumably be able to counter this chemical defense in order to establish a successful parasitic relationship. The ability to hydrolyze $\alpha$-tomatine to less toxic products by fungal extracellular enzymes (tomatinases) represents one potential mechanism for achieving this. Here we have generated mutants of $S$. lycopersici that are unable to degrade $\alpha$ tomatine by targeted replacement of the tomatinase gene. Enzyme assays confirmed that tomatinase activity was not detectable in culture filtrates of these mutants. Tomatinase gene replacement mutants were clearly more sensitive to $\alpha$ tomatine when compared with tomatinase-producing control strains, and this increased sensitivity was evident at $\alpha$ tomatine concentrations as low as $25 \mu \mathrm{M}$. However, the mutants could still grow in the presence of $1 \mathrm{mM} \alpha$-tomatine (Table 1).

Loss of tomatinase had no obvious effects on pathogenicity of the mutants to different Lycopersicon accessions. There also is no evidence to indicate that $S$. lycopersici produces additional $\alpha$-tomatine-hydrolyzing activities, either in vitro or in planta. If $\alpha$-tomatine does indeed represent a barrier to infection of tomato leaves by $S$. lycopersici, other mechanisms of resistance to this steroidal glycoalkaloid in addition to degradation by tomatinase must presumably exist. Since many saponins are able to permeabilize fungal membranes, apparently by forming complexes with membrane sterols (Keukens et al. 1992; Keukens et al. 1995; Nishikawa et al. 1984; Schulz and Sander 1957), membrane sterol content may represent one mechanism of intrinsic resistance (Aparna et al. 1998; Arneson and Durbin 1968b; Défago and Kern 1983; Senegupta et al. 1995). Nondegradative tolerance mechanisms including membrane efflux processes are also likely to be important in protecting phytopathogenic fungi from antimicrobial plant secondary metabolites (Denny and Van Etten 1983; Denny et al. 1987; De Waard 1997; Urban et al. 1999). In our experiments only five tomatinase gene replacement mutants were identified among 650 transformants. When all 650 transformants were grown on $\alpha$-tomatine the five gene replacement mutants could be readily distinguished as having increased sensitivity to $\alpha$-tomatine, but transformants with increased sensitivity that had undergone ectopic (random) insertion of the transforming DNA in genes other than the tomatinase gene were not identified. Additional mutational analysis is required in order to identify other factors that determine steroidal glycoalkaloid resistance in S. lycopersici and other pathogens of solanaceous plants.

Microscopic analysis of the infection process confirmed that infection occurs primarily via stomata, as reported by Sohi and Sokhi (1972). The fungus colonized leaf tissue at the margins of expanding lesions by growing in the intercellular spaces of the host, forming dichotomous branches around mesophyll cells in a manner that bore striking similarity to the behavior of the biotrophic tomato pathogen Cladosporium fulvum (De Wit 1977; Lazarovitz and Higgins 1976). The distribution and compartmentalization of $\alpha$-tomatine within the leaf tissue is unclear, although subcellular fractionation experiments indicate that the steroidal glycoalkaloid is mainly in the soluble fraction and so may accumulate in the vacuoles and/or soluble phase of the cytoplasm (Roddick 1976; Roddick 1977). The young, actively growing hyphae that invade healthy plant tissue may avoid encountering inhibitory levels of $\alpha$-tomatine during early colonization when there is little damage to host cells. However, S. lycopersici clearly differs from $C$. fulvum in that it causes substantial cell death and lesion development in the later stages of infection, and this will inevitably result in the release of $\alpha$-tomatine.

The leaves of different Lycopersicon species and accessions show considerable variation in $\alpha$-tomatine content (Juvik et al. 1982). L. pimpinellifolium accessions LA 1248 and LA 1335 were included in these experiments because they are reported to contain moderate and high levels of $\alpha$-tomatine, respectively (Juvik and Stevens 1982; Juvik et al. 1982). LA 1248 was clearly more susceptible than LA 1335 to the S. lycopersici strain used in our experiments. Interestingly, genetic analysis of progeny derived from a cross between LA 1248 and LA 1335 has revealed that $\alpha$-tomatine content is likely to be determined by the segregation of two codominant alleles of a single gene (Juvik and Stevens 1982). However, since progeny with different $\alpha$-tomatine levels were not assessed for resistance to tomato pathogens, it is not clear whether $\alpha$ - 
tomatine content is correlated with disease resistance. Obviously, Lycopersicon accessions are likely to differ in many factors that influence resistance to $S$. lycopersici, in addition to $\alpha$-tomatine content. This is reflected by the observation that the L. esculentum cultivar used in our experiments (Moneymaker CfO) developed only small sporadic lesions when inoculated with S. lycopersici. L. esculentum cultivars generally contain levels of $\alpha$-tomatine lower than those of either of these L. pimpinellifolium accessions (Juvik et al. 1982).

Although there were no obvious effects of tomatinase gene replacement on macroscopic symptom development, trypan blue staining of leaves prior to lesion development indicated that plant cell death was enhanced in leaves that had been inoculated with tomatinase-minus mutants compared with the wild-type and control strains. This aberrant plant response may be triggered by subtle differences in the growth of the fungal strains within the leaf tissue, although this was not apparent from microscopic analysis. An alternative explanation could be that in the wild-type fungus tomatinase itself or the product of its action, $\beta_{2}$-tomatine, is in some way involved in suppression of plant defense responses. There is evidence to suggest that various fungi may produce molecules that suppress plant defense responses (Kessman and Barz 1986; Shiriashi et al. 1992; Zeigler and Ponzen 1982), and the extracellular proteins ECP1 and ECP2, produced by $C$. fulvum during colonization of the intercellular spaces of tomato leaves, also have been implicated as suppressors (Laugé et al. 1997). S. lycopersici tomatinase does not share sequence similarity with either of these $C$. fulvum proteins, but it may also act as an extracellular suppressor. Previously we have demonstrated that heterologous expression of $S$. lycopersici tomatinase in $C$. fulvum resulted in increased sporulation on susceptible tomato lines and also more extensive colonization of resistant tomato lines, suggesting that $\alpha$-tomatine may be present in apoplastic spaces and may restrict the growth of this biotroph in planta (Melton et al. 1998). The interpretation of these experiments may need to be reconsidered if further experiments indicate that tomatinase does indeed suppress plant defenses.

\section{MATERIALS AND METHODS}

Culture methods for $S$. lycopersici.

The $S$. lycopersici strain used in this study was NEV, which originates from Nevada, Iowa, U.S.A. (Parker et al. 1997), and was provided by R. Sandrock. The isolate was stored on potato dextrose agar (PDA) slopes under mineral oil at $4^{\circ} \mathrm{C}$, as described by Osbourn et al. (1995). Cultures were grown on Czapek Dox V8 agar containing $200 \mathrm{ml}$ of V8 vegetable juice (Campbell Grocery Products Ltd., Kings Lynn, U.K.), 2 g of calcium carbonate, and $10 \mathrm{~g}$ of Czapek Dox agar (Oxoid, Hampshire, U.K.) per liter and incubated in the dark at $22^{\circ} \mathrm{C}$. Conidia were harvested after 2 weeks by flooding the plates
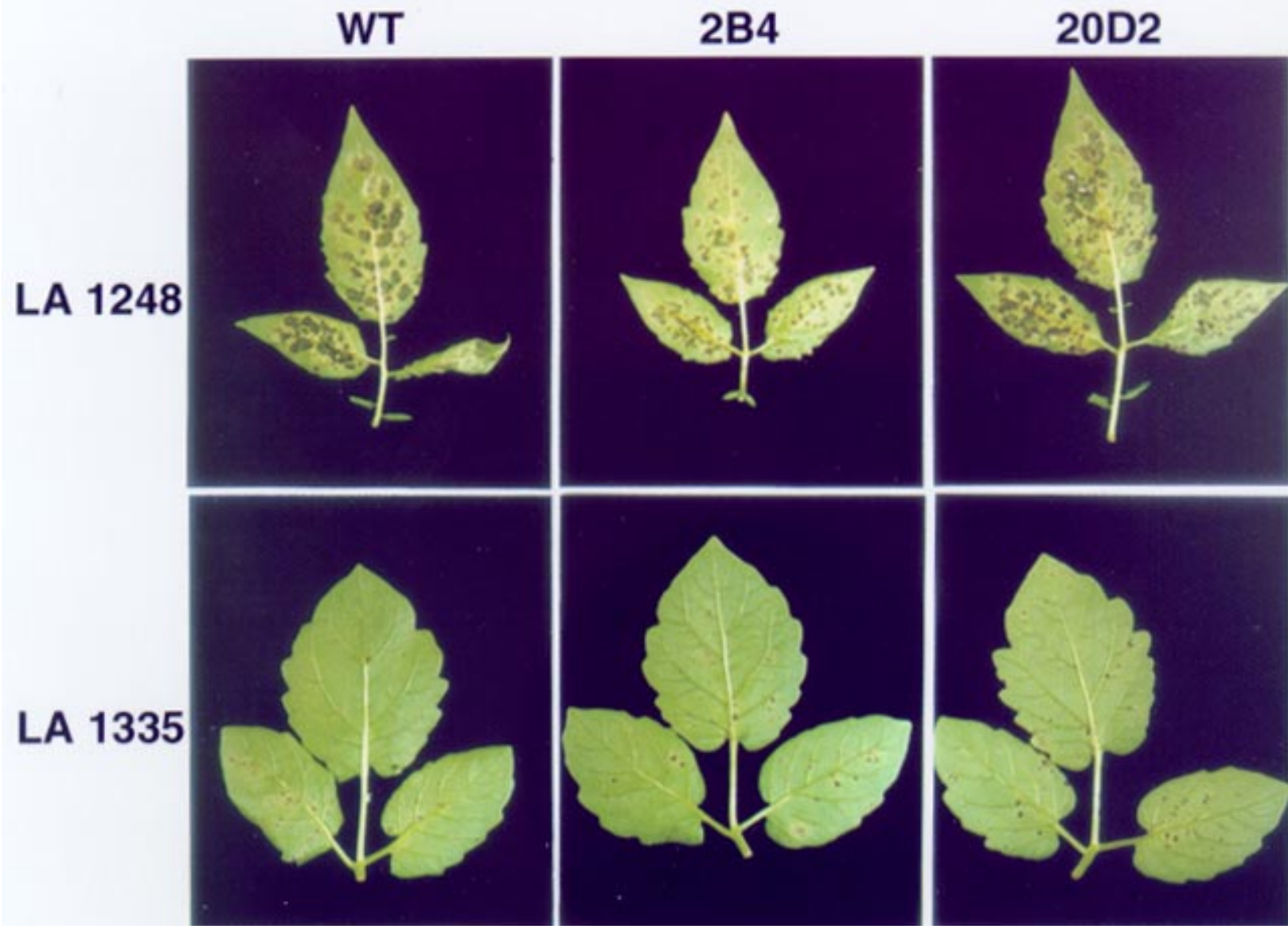

Fig. 4. Leaves of Lycopersicon pimpinellifolium accessions 1248 and 13351 week after inoculation with the wild-type Septoria lycopersici strain NEV (WT), an ectopic transformant (2B4), and a gene replacement mutant (20D2). 
with $0.01 \%$ Tween 80 detergent (Sigma, St. Louis, MO, U.S.A.) and scraping the surface of the colonies with a glass spreader. The spore suspension was filtered through two layers of Miracloth (Calbiochem, La Jolla, CA, U.S.A.), and the spores were harvested by centrifugation at $2,225 \times g$ for 10 min before resuspension in $0.01 \%$ Tween 80 .

For isolation of fungal DNA, $10^{8}$ spores were inoculated into $50 \mathrm{ml}$ of Czapek Dox V8 liquid medium and the cultures were grown at $22^{\circ} \mathrm{C}$ with shaking $(200 \mathrm{rpm})$ for 6 days. Czapek Dox V8 liquid medium contains, per liter, $200 \mathrm{ml}$ of V8 vegetable juice, $2 \mathrm{~g}$ of calcium carbonate, $45 \mathrm{~g}$ of Czapek Dox liquid medium, and $10 \%$ supplement mix (20 g casamino acids, $20 \mathrm{~g}$ peptone, $20 \mathrm{~g}$ yeast extract, $3 \mathrm{~g}$ adenine, $20 \mathrm{mg}$ biotin, $20 \mathrm{mg}$ thiamine, $20 \mathrm{mg} p$-aminobenzoic acid, and 20 $\mathrm{mg}$ nicotinic acid per liter).

For measurement of the effects of $\alpha$-tomatine on fungal growth, tests were routinely carried out on Czapek Dox V8 agar, but complete medium (CM) was also used. CM contains $10 \mathrm{~g}$ of glucose, $2 \mathrm{~g}$ of peptone, $1 \mathrm{~g}$ of casamino acids, $1 \mathrm{~g}$ of yeast extract, $6 \mathrm{~g}$ of sodium nitrate, $0.5 \mathrm{~g}$ of potassium chloride, $0.5 \mathrm{~g}$ of magnesium sulfate, $1.5 \mathrm{~g}$ of potassium dihydrogen orthophosphate, and $20 \mathrm{~g}$ of agar per liter. Stock solutions (1-mM) of $\alpha$-tomatine (Sigma) were prepared in $50 \mathrm{mM}$ potassium acetate buffer, $\mathrm{pH}$ 4.5. Control plates received buffer alone. Agar plates were inoculated with $1-\mathrm{mm}^{3}$ blocks of mycelium from fresh stock plates (five replicate colonies per treatment) and incubated in the dark at $22^{\circ} \mathrm{C}$. Growth was monitored by measurement of colony diameters. Streptomycin sulfate $(50 \mu \mathrm{g} / \mathrm{ml})$ was added routinely to all culture media.

\section{Plant infection experiments.}

Pathogenicity assays were carried out on L. pimpinellifolium accessions LA 1248 and LA 1335 (Juvik et al. 1982) and Moneymaker $C f O$. Plants were grown in a growth cabinet at $25^{\circ} \mathrm{C}$, with a 15 -h photoperiod. Detached leaves of 4-week-old plants were inoculated by brushing the underside with spore suspensions of $S$. lycopersici strain NEV $\left(1 \times 10^{6}\right.$ spores $/ \mathrm{ml}$ in $0.01 \%$ Tween 80 detergent). Mock-inoculated leaves were brushed with $0.01 \%$ Tween 80 only. Spore viability was monitored by plating dilution series of the spore suspensions onto PDA and counting the colonies after incubation in the dark at $22^{\circ} \mathrm{C}$ for 5 days. Inoculated leaves were placed underside uppermost on damp filter paper in $9 \mathrm{~cm}$-petri dishes. The dish lids were sprayed with sterile distilled water, and the dishes sealed with Parafilm (American National Can, Menasha, WI, U.S.A.). The leaves were incubated at $25^{\circ} \mathrm{C}$ with a 16-h day.

For microscopic analysis, five to ten leaves per host genotype-fungal strain combination were sampled $0,2,4,6$, and 8 days after inoculation. The leaves were stained with trypan blue/lactophenol in 50-ml tubes (Corning Inc., Corning, NY, U.S.A.), as described in Melton et al. (1998). Leaflets were viewed with an Axioskop microscope (Carl Zeiss Ltd., Welwyn Garden City, Hertfordshire, U.K.) under bright-field illumination at 100- and 200-fold magnification. Photographs were taken with Kodak Ektochrome 160 tungsten film (Eastman Kodak Co., Rochester, NY, U.S.A.), and six independent experiments were conducted.

To recover apoplastic fluid, inoculated leaves of $L$. pimpinellifolium accession LA 1248 or Moneymaker CfO (four leaves per host-per fungus combination) were placed in plas-

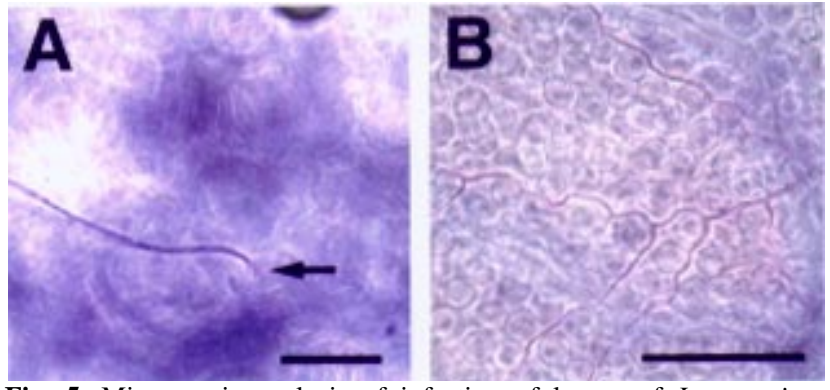

Fig. 5. Microscopic analysis of infection of leaves of Lycopersicon pimpinellifolium accession LA 1248 by Septoria lycopersici strain NEV. A, Fungal hypha infecting via a stoma (the arrow indicates the site of host penetration). B, Hyphae growing intercellularly within the leaf mesophyll at the margin of an expanding lesion. Leaves were stained with lactophenol-trypan blue 8 days after inoculation, and leaflets were observed under bright-field illumination. Scale bars $=50 \mu \mathrm{m}$.
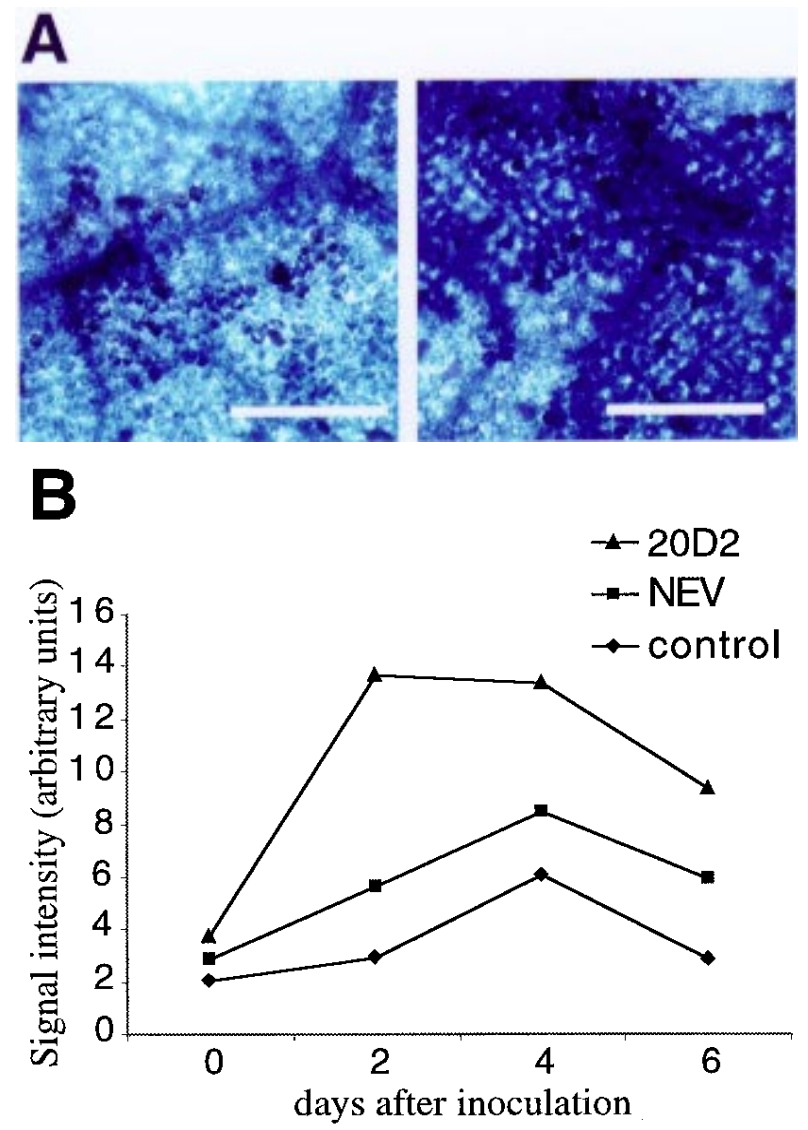

Fig. 6. Response of leaves of Lycopersicon pimpinellifolium accession LA 12484 days after inoculation. A, Staining of leaf tissue with lactophenol-trypan blue consistently revealed substantially more bluestained (i.e., dying) host cells in leaves inoculated with the tomatinaseminus mutant 20D2 (right panel) compared with the wild-type strain (left panel). Scale bars $=50 \mu \mathrm{m}$. B, Time course of expression of basic $\beta$-1,3-glucanase mRNA in detached leaves of $L$. pimpinellifolium accession 1248 following infection by the Septoria lycopersici wild-type strain NEV or the tomatinase-minus mutant 20D2, and in mockinoculated leaves. For the zero time point, leaves were harvested immediately after inoculation. Arbitrary units correspond to the integration of each hybridizing signal on the autoradiogram using the Fujix Bas1000 system (Fuji, U.K.). The signal intensity for each sample was normalized to a constant value of total RNA. 
tic tip boxes (Rainin Instrument Co., Woburn, MA, U.S.A.) filled with sterile distilled water. The tip rack was upturned and placed on top of the water to keep the leaves immersed. The air was evacuated from the sample for $10 \mathrm{~min}$ by a vacuum pump and the vacuum was then released slowly. This process was repeated twice more. Excess water was removed from the leaves by blotting with Kimwipes (Kimberly-Clark, Reigate, U.K.). The leaves were rolled up and inserted into a 20-ml syringe (Terumo, Leuven, Belgium), without the plunger. The syringe tip was cut off and six to eight holes pierced in the bottom, and the syringe was put into a $50-\mathrm{ml}$ tube (Corning) and centrifuged at $1,865 \times g$ for $20 \mathrm{~min}$ at $8^{\circ} \mathrm{C}$. The apoplastic fluid that collected in the tube was freeze-dried overnight. Protein concentrations and tomatinase activity were assessed following resuspension in $30 \mu \mathrm{l}$ of sterile water.

\section{DNA manipulations and library construction.}

DNA manipulations were carried out by standard techniques (Sambrook et al. 1989). Genomic DNA of S. lycopersici strain NEV was isolated from frozen mycelium in the presence of DNA isolation buffer $(0.5 \mathrm{M} \mathrm{NaCl}, 10 \mathrm{mM}$ Tris$\mathrm{HCl}, \mathrm{pH} 7.5,10 \mathrm{mM}$ EDTA, $1 \%$ sodium dodecyl sulfate (SDS); $10 \mathrm{ml} / \mathrm{g}$ of mycelium), followed by phenol extraction and isopropanol precipitation (Cooley et al. 1988). For library construction, fungal genomic DNA was partially digested with $T s p E$ I restriction enzyme. DNA fragments of 8 to $10 \mathrm{~kb}$ were purified from a $1 \%$ agarose gel by standard methods and cloned into the bacteriophage vector lambda ZapII with the lamba ZAPII/EcoRI/CIAP cloning kit (Stratagene, La Jolla, CA, U.S.A.). Packaging, amplification, and screening of the library were carried out as recommended by Stratagene. The tomatinase cDNA probe for Southern blot analysis and library screening was amplified from the plasmid pCTOM6 (Osbourn et al. 1995) using PCR primers 1 (5'-GTTCAACATCGCTGCCCTTGC-3') and 2 (5'-GCCGAGCCTCTGGGCCGGCGC$\left.3^{\prime}\right)$ (Fig. 2) and simultaneously labeled using the nonisotopic digoxigenin labeling kit following the kit manufacturer's instructions (Boehringer Mannheim, Mannheim, Germany). Hybridizations for Southern blot analysis were carried out in DIG Easy buffer (Boehringer Mannheim) at $42^{\circ} \mathrm{C}$, with two

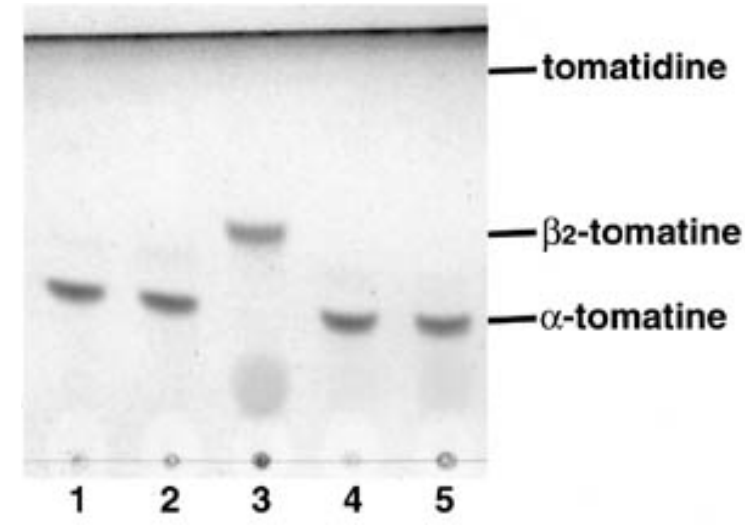

Fig. 7. Thin-layer chromatography of the degradation of $\alpha$-tomatine by intercellular fluid preparations from inoculated leaves of Lycopersici esculentum cv. Moneymaker CfO. Lane 1, mock-inoculated treatment 10 days post-inoculation (dpi); lanes 2 and 3, wild-type inoculum 3 and 10 dpi, respectively; lanes 4 and 5, tomatinase gene replacement mutant 20D2 3 and $10 \mathrm{dpi}$, respectively. The migration positions of $\alpha$-tomatine, $\beta_{2}$-tomatine and tomatidine are indicated on the right. 10-min washes at room temperature in $2 \times$ SSC and $0.1 \%$ SDS followed by two $15-\mathrm{min}$ washes at $68^{\circ} \mathrm{C}$ in $1 \times \mathrm{SSC} / 0.1 \% \mathrm{SDS}$ ( $1 \times \mathrm{SSC}$ is $0.15 \mathrm{M} \mathrm{NaCl}, 0.015 \mathrm{M}$ sodium citrate). Hybridizations for library screening were carried out at $40^{\circ} \mathrm{C}$ in DIG Easy buffer (Boehringer Mannheim) with washing at $40^{\circ} \mathrm{C}$ in $0.5 \times \mathrm{SSC} / 0.1 \%$ SDS. Positive plaques were isolated and following two additional rounds of purification the phage was recovered by cutting out the agar containing the plaque. The cored plaque was immersed in $200 \mu \mathrm{l}$ of SM buffer (Stratagene) and incubated at $4{ }^{\circ} \mathrm{C}$ overnight to allow the phage to diffuse out of the agar. The samples were then centrifuged to eliminate agar, and $5 \mu 1$ of supernatant was used for phage-PCR analysis. The PCR screen was carried out with Expand HiFi Taq polymerase (Boehringer Mannheim), and the reaction conditions consisted of $2 \mathrm{~min}$ at $94^{\circ} \mathrm{C}, 10$ cycles of $15 \mathrm{~s}$ at $94^{\circ} \mathrm{C}, 30 \mathrm{~s}$ at $62^{\circ} \mathrm{C}, 1 \mathrm{~min}$ at $68^{\circ} \mathrm{C}$, and 20 cycles of the same conditions but with an additional $15 \mathrm{~s}$ elongation per cycle.

The PCR primers used were the extended pBluescript T3 (5'-AGCTCGAAATTAACCCTCACTAAAGGG-3') and T7 (5'-GAATTGTAATACG-ACTCACTATAGGGC-3') primers, and $5^{\prime}$ tom (5'-CCCAGCAAGGGCAGCG-ATGTTGAAC-3') and $3^{\prime}$ tom (5'-GCTCAAGAGACATCAAGTCTATCGTTTC$3^{\prime}$ ), which prime outward from the tomatinase gene (annealing at nucleotides 15 to 39 and 2539 to 2567 of the coding sequence of the gene, respectively). Phagemids were then excised following the supplier's instructions and analyzed further by restriction mapping.

\section{Northern blot analysis.}

Four leaves per host-strain combination were collected for each time point $(0,2,4$, and 6 days after inoculation), pooled and frozen in liquid nitrogen. Total RNA was isolated from frozen leaf tissue using the RNeasy Plant Mini Kit (Qiagen, Crawley, U.K.) and the RNA quantified spectrophotometrically. RNA samples (approximately $5 \mu \mathrm{g}$ per lane) were separated by formamide-agarose gel electrophoresis and transferred to nylon membranes $\mathrm{N}^{+}$(Amersham Pharmacia Biotech, St. Albans, U.K.) by capillary elution (Sambrook et al. 1989). A 1.5-kb EcoRI/XhoI restriction fragment for the basic intracellular $\beta$-1,3-glucanase from $L$. esculentum (GenBank accession number M80608; Van Kan et al. 1992) was radiolabeled with ${ }^{32} \mathrm{P}$ by random priming using the Oligolabeling kit (Amersham Pharmacia Biotech). Hybridizations were carried out at $65^{\circ} \mathrm{C}$ in sodium phosphate hybridization buffer (Church and Gilbert 1984), with washing at $65^{\circ} \mathrm{C}(2 \times$ $20 \mathrm{~min}$ in $2 \times \mathrm{SSC}, 0.1 \% \mathrm{SDS} ; 1 \times 15 \mathrm{~min}$ in $0.5 \times \mathrm{SSC}, 0.1 \%$ SDS).

\section{Tomatinase gene disruption.}

For construction of the plasmid for targeted gene disruption, pGTOM1 was digested with the restriction enzyme NdeI, gel purified, blunt-ended with Klenow (Boehringer Mannheim) and then treated with shrimp alkaline phosphatase (Boehringer Mannheim). The internal 1.1-kb NdeI fragment, which includes the region of the gene encoding an aspartate residue that is predicted to be the catalytic residue (Osbourn et al. 1995; Sandrock et al. 1995), was replaced with a 1.4-kb HpaI restriction fragment containing the Escherichia coli hygromycin phosphotransferase $(h p h)$ gene under the control of the Aspergillus nidulans $\operatorname{TrpC}$ promoter. This $h p h$ cassette was 
excised from the plasmid pCB1004 (Carroll et al. 1994) using the restriction enzyme $H p a \mathrm{I}$, gel-purified and ligated into the NdeI-digested pGTOM1 vector. This plasmid was linearized with NotI prior to use in fungal transformation experiments.

Fungal protoplasts were prepared as follows. Czapek Dox V8 liquid medium $(200 \mathrm{ml})$ was inoculated with $10^{7}$ spores of $S$. lycopersici strain NEV and the cultures incubated at $22^{\circ} \mathrm{C}$ in the dark for 2 days with shaking at $200 \mathrm{rpm}$. Mycelium was harvested by filtering through four layers of Miracloth and digested with $5 \mathrm{mg}$ of Novozyme 234 (Interspex Products, Foster City, CA, U.S.A.) per milliliter in 1.2 M magnesium sulfate, $10 \mathrm{mM}$ sodium phosphate, $\mathrm{pH} 5.8$ (with $2.5 \mathrm{ml}$ of Novozyme 234 solution per gram of wet mycelium). Digestion was carried out at $32^{\circ} \mathrm{C}$ without shaking for 2 to $3 \mathrm{~h}$. Protoplasts were then harvested by filtration through four layers of Miracloth. The filtrate was overlaid carefully with an equal volume of $0.6 \mathrm{M}$ sorbitol and $100 \mathrm{mM}$ Tris- $\mathrm{HCl}, \mathrm{pH} 7$ and centrifuged at $4,000 \times g$ for $25 \mathrm{~min}$. The protoplasts, which were retained at the interface, were collected with a Pasteur pipette and mixed with an equal volume of STC (1.2 $\mathrm{M}$ sorbitol, $10 \mathrm{mM}$ calcium chloride, and $10 \mathrm{mM}$ Tris $\mathrm{HCl}$, $\mathrm{pH} 7)$. After subsequent centrifugation the pellet was washed with STC and protoplasts were resuspended in the same buffer to a concentration of $5 \times 10^{8}$ per ml. Protoplasts $\left(2 \times 10^{7}\right)$ were transformed with $8 \mu \mathrm{g}$ of NotI-linearized pGTOMD in the presence of $50 \mathrm{mM} \mathrm{CaCl} 2$ and 25\% PEG 6000 (Sigma) and plated in minimal medium (Newton and Caten 1988) supplemented with $1 \mathrm{M}$ sucrose. Forty hours later, the plates were overlaid with minimal medium containing $7.5 \mathrm{~g}$ of agar per liter and $200 \mu \mathrm{g}$ of hygromycin B and $50 \mu \mathrm{g}$ of streptomycin sulfate per milliliter. Hygromycin-resistant regenerants were picked 12 days after transformation and purified three times by subculturing on Czapek Dox V8 agar containing $50 \mu \mathrm{g}$ of hygromycin B and $50 \mu \mathrm{g}$ of streptomycin sulfate per milliliter.

\section{Screening of transformants.}

Transformants were initially screened by PCR for disruption of the tomatinase gene. Transformants were grown in Czapek Doz V8 liquid medium, and DNA prepared as described in Ross (1995). The DNA was resuspended in $100 \mu \mathrm{l}$ of Tris-EDTA, diluted 100-fold, and $1 \mu \mathrm{l}$ of the diluted preparation was used for PCR using Taq DNA polymerase (Pharmacia). PCR was performed first with primers $4\left(5^{\prime}\right.$ CAGCGAGAGCCTGACCTATTGC-3') and 5 (5'-GCCATCGGTCCAGACGGCCGCGC-3'), which amplify the $h p h$ cassette $\left(35\right.$ cycles of $30 \mathrm{~s}$ at $94^{\circ} \mathrm{C}, 30 \mathrm{~s}$ at $57^{\circ} \mathrm{C}, 45 \mathrm{~s}$ at $72^{\circ} \mathrm{C}$ ). The positives were then tested for the absence of the wild-type tomatinase gene using primers 1 (5'-GTTCAACATCGCTGCCCTTGC-3') and 3 (5'-CGCGAGCAGGCGGGGGG-3'), with PCR conditions of 35 cycles of $30 \mathrm{~s}$ at $94^{\circ} \mathrm{C}, 30 \mathrm{~s}$ at $52^{\circ} \mathrm{C}$, and $1 \mathrm{~min} 15 \mathrm{~s}$ at $72^{\circ} \mathrm{C}$. Primer 3 anneals in the region that is absent in the disrupted plasmid pGTOMD (Fig. 2), which enabled ectopic insertion and gene replacement events to be distinguished. Gene replacement was confirmed by Southern blot analysis of BamHI-digested genomic DNA using the full length tomatinase cDNA as a probe.

\section{Tomatinase assays.}

Fungal cultures $(100 \mathrm{ml})$ for use in tomatinase assays were grown in Czapek Dox liquid medium containing casamino acids (10 g per liter), as described in Osbourn et al. (1995), with the exception that the medium was inoculated with spores $\left(1 \times 10^{7}\right)$ rather than mycelium. Cultures were harvested 3 to 10 days later, and the filtrates were recovered by filtering the cultures through Miracloth. Proteins were concentrated by ammonium sulfate precipitation, as described in Osbourn et al. (1995), and then resuspended and dialyzed against sterile water. Protein concentrations were determined with the BioRad Protein Assay (BioRad, Richmond, CA, U.S.A.) using bovine serum albumen as a standard.

Culture filtrate concentrates and preparations from intercellular fluid of leaves were assayed for the ability to release $\mathrm{D}$-glucose from $\alpha$-tomatine using the glucose oxidase assay kit (Sigma), as described in Osbourn et al. (1995). Modification of $\alpha$-tomatine also was monitored by TLC as described in Melton et al. (1998) but with chloroform, methanol, and 1\% ammonium hydroxide $(65: 35: 5, \mathrm{vol} / \mathrm{vol} / \mathrm{vol})$ as the solvent. Reference standards for TLC analysis were $\alpha$-tomatine and the corresponding aglycone tomatidine (Sigma) and $\beta_{2^{-}}$ tomatine (prepared by hydrolysis of $\alpha$-tomatine with $S$. $l y$ copersici tomatinase). The other glycosylation intermediates, $\beta_{1}$-tomatine, $\gamma$-tomatine, and $\delta$-tomatine, were generated by acid hydrolysis as described by Friedman et al. (1998).

\section{ACKNOWLEDGMENTS}

The Sainsbury Laboratory is supported by the Gatsby Charitable Foundation. Part of this work was sponsored by Biotechnology and Biological Sciences Research Council grant \#PO1216 (VH) and Marie Curie European Community fellowships to A. M. Martin-Hernandez and M. Dufresne.

\section{LITERATURE CITED}

Aparna, K., Sandrock, R. W., and Kasbekar, D. P. 1998. Cloning of the sterol C-14 reductase gene of the tomato pathogenic fungus Septoria lycopersici and its complementation of the erg-3 mutation of $\mathrm{Neu}$ rospora crassa. J. Genet. 77:71-75.

Arneson, P. A., and Durbin, R. D. 1967. Hydrolysis of tomatine by Septoria lycopersici: A detoxification mechanism. Phytopathology 57:13581360.

Arneson, P. A., and Durbin, R. D. 1968a. Studies on the mode of action of tomatine as a fungitoxic agent. Plant Physiol. 43:683-686.

Arneson, P. A., and Durbin, R. D. 1968b. The sensitivity of fungi to $\alpha$ tomatine. Phytopathology 58:536-537.

Bowyer, P., Clarke, B. R., Lunness, P., Daniels, M. J., and Osbourn, A. E. 1995. Host range of a plant pathogenic fungus determined by a saponin detoxifying enzyme. Science 267: 371-374.

Carroll, A. M., Sweigard, J. A., and Valent, B. 1994. Improved vectors for selecting resistance to hygromycin. Fungal Genet. Newsl. 41:22-23.

Carter, J. P., Spink J., Cannon, P., Daniels M. J., and Osbourn A. E. 1999. Isolation, characterization and avenacin sensitivity of a diverse collection of cereal root colonizing fungi. Appl. Environ. Microbiol. 65:33643372.

Church, G. M., and Gilbert, W. 1984. Genomic sequencing. Proc. Natl. Acad. Sci. USA 81:1991-1995.

Cooley, R. N., Shaw, R. K., Franklin, F. C. H., and Caten, C. E. 1988. Transformation of the phytopathogenic fungus Septoria nodorum to hygromycin B resistance. Curr. Genet. 13:383-389.

Crombie, W. M. L., Crombie, L., Green, J. B., and Lucas, J. A. 1986. Pathogenicity of the take-all fungus to oats: Its relationship to the concentration and detoxification of the four avenacins. Phytochemistry 25:2075-2083.

De Waard, M. A. 1997. Significance of ABC transporters in fungicide sensitivity and resistance. Pestic. Sci. 51:271-275.

De Wit, P. J. G. M. 1977. A light and scanning-electron microscopic study of infection of tomato plants by avirulent and virulent races of Cladosporium fulvum. Neth. J. Plant Pathol. 83:109-122.

De Wit, P. J. G. M., and Spikman, G. 1982. Evidence for the occurrence 
of race- and cultivar-specific elicitor in intercellular fluids of compatible interactions of Cladosporium fulvum and tomato. Physiol. Plant Pathol. 21:1-11.

Défago, G., and Kern, H. 1983. Induction of Fusarium solani mutants insensitive to tomatine, their pathogenicity and aggressiveness to tomato fruits and pea plants. Physiol. Plant Pathol. 22:29-37.

Denny, T. P., Matthews, P. S., and Van Etten, H. D. 1987. A possible mechanism of nondegradative tolerance of pisatin in Nectria haematococca MP VI. Physiol. Mol. Plant Pathol. 30:93-107.

Denny, T. P., and VanEtten, H. D. 1983. Characterization of an inducible, nondegradative tolerance of Nectria haematococca MP VI to phytoalexins. J. Gen. Microbiol. 129:2903-2913.

Durbin, R. D., and Uchytil, T. F. 1969. Purification and properties of a fungal $\beta$-glucosidase acting on $\alpha$-tomatine. Biochim. Biophys. Acta 191:176-178.

Fenwick, G. R., Price, K. R., Tsukamato, C., and Okubo, K. 1992. Saponins. Pages 285-327 in Toxic Substances in Crop Plants. J. P. D'Mello, C. M. Duffus, and J. H. Duffus, eds. The Royal Society of Chemistry, Cambridge, U.K.

Ford, J. E., McCance, D. J., and Drysdale, R. B. 1977. The detoxification of $\alpha$-tomatine by Fusarium oxysporum. f. sp. lycopersici. Phytochemistry 16:544-546.

Friedman, M., Kozukue, N., and Harden, L. A. 1998. Preparation and characterization of acid hydrolysis products of the tomato glycoalkaloid $\alpha$-tomatine. J. Agric. Food Chem. 46: 2096-2101.

Hostettmann, K. A., and Marston, A. 1995. Saponins. Chemistry and Pharmacology of Natural Products. Cambridge University Press, Cambridge, U.K

Juvik, J. A., and Stevens, M. A. 1982. Inheritance of foliar $\alpha$-tomatine content in tomatoes. J. Am. Soc. Hortic. Sci. 107:1061-1065.

Juvik, J. A., Stevens, M. A., and Rick C. M. 1982. Survey of the genus Lycopersicon for variability in $\alpha$-tomatine content. HortScience 17:764-766.

Kessman, H., and Barz, W. 1986. Elicitation and suppression of phytoalexin and isoflavone accumulation in cotyledons of Cicer arietinum $\mathrm{L}$. as caused by wounding and polymeric components from the fungus Ascochyta rabiei. J. Phytopathol. 117: 321-325.

Keukens, E. A. J., De Vrije, T., Fabrie, C. H. J. P., Demel, R. A., Jongen, W. M. F., and De Kruijff, B. 1992. Dual specificity of sterol-mediated glycoalkaloid induced membrane disruption. Biochim. Biophys. Acta 1110:127-136.

Keukens, E. A. J., De Vrije, T., Van den Boom, C., De Waard, P., Plasmna, H. H., Thiel, F., Chupin, V., Jongen, W. M. F., and De Kruijff, B. 1995. Molecular basis of glycoalkaloid induced membrane disruption. Biochim. Biophys. Acta 1240:216-228.

Lairini, K., Perez-Espinosa, A., Pineda, M., and Ruiz-Rubio, M. 1996. Purification and characterization of tomatinase from Fusarium oxysporum f. sp. lycopersici. Appl. Environ. Microbiol. 62:1604-1609.

Laugé, R., Joosten, M. H. A. J., Van den Ackerveken, G. F. J. M., Van den Broek, H. W. J., and De Wit, P. J. G. M. 1997. The in plantaproduced extracellular proteins ECP1 and ECP2 of Cladosporium fulvum are virulence factors. Mol. Plant-Microbe Interact. 10:725-734.

Lazarovitz, G., and Higgins, V. J. 1976. Ultrastructure of susceptible, resistant and immune reactions of tomato to races of Cladosporium fulvum. Can. J. Bot. 54:235-249.

Lüning, H. U., and Schlösser, E. 1976. Role of saponins in antifungal resistance VI. Interactions Avena sativa-Drechslera avenacea. J. Plant Dis. Prot. 83:317-327.

Melton, R. E., Flegg, L. M., Brown, J. K. M., Oliver, R. P., Daniels, M. J., and Osbourn, A. E. 1998. Heterologous expression of Septoria lycopersici tomatinase in Cladosporium fulvum: Effects on compatible and incompatible interactions with tomato seedlings. Mol. PlantMicrobe Interact. 11:228-236.

Morrissey, J. P., and Osbourn, A. E. 1999. Fungal resistance to plant antibiotics as a mechanism of pathogenesis. Microbiol. Mol. Biol. Revs. 63:708-724.

Newton, A. C., and Caten, C. E. 1988. Auxotrophic mutants of Septoria nodorum isolated by direct screening and by selection for resistance to chlorate. Trans. Br. Mycol. Soc. 90:199-207.

Nishikawa, M., Nojima, S., Akiyama, T., Sankawa, U., and Inoue, K. 1984. Interaction of digitonin and its analogs with membrane cholesterol. J. Biochem. (Tokyo) 96:1231-1239.

Osbourn, A. E. 1996. Saponins and plant defense: A soap story. Trends Plant Sci. 1: 4-9.
Osbourn, A. E. 1999. Antimicrobial phytoprotectants and fungal pathogens: A commentary. Fungal Genet. Biol. 26:163-168.

Osbourn, A. E., Bowyer, P., Lunness, P., Clarke, B., and Daniels, M. 1995. Fungal pathogens of oat roots and tomato leaves employ closely related enzymes to detoxify host plant saponins. Mol. PlantMicrobe Interact. 8:971-978.

Osbourn, A. E., Clarke, B. R., Dow, J. M., and Daniels, M. J. 1991 Partial characterization of avenacinase from Gaeumannomyces graminis var. avenae. Physiol. Mol. Plant Pathol. 38:301-312.

Osbourn, A. E., Clarke, B. R., Lunness, P., Scott, P. R., and Daniels, M. J. 1994. An oat species lacking avenacin is susceptible to infection by Gaeumannomyces graminis var. tritici. Physiol. Mol. Plant Pathol. 45:457-467.

Papadopoulou, K., Melton, R. E., Leggett, M., Daniels, M. J., and Osbourn, A. E. 1999. Compromised disease resistance in saponindeficient plants. Proc. Natl. Acad. Sci. USA 96:12923-12928.

Parker, S. K., Nutter Jr., F. W., and Gleason, M. L. 1997. Directional spread of Septoria leaf spot in tomato rows. Plant Dis. 81:272-276.

Pegg, G. F., and Woodward, S. 1986. Synthesis and metabolism of $\alpha-$ tomatine in tomato isolines in relation to resistance to Verticillium albo-atrum. Physiol. Mol. Plant Pathol. 28:187-201.

Perelló, A., Wolcan, S., and Alippi, H. 1991. Una variante miceliar albina de Septoria lycopersici Speg. Turrialba 41:190-195.

Price, K. R., Johnson, I. T., and Fenwick, G. R. 1987. The chemistry and biological significance of saponins in foods and feedingstuffs. CRC Crit. Rev. Food Sci. Nutr. 26:27-133.

Quidde, T., Osbourn, A., and Tudzynski, P. 1998. Detoxification of $\alpha$ tomatine by Botrytis cinerea. Physiol. Mol. Plant Pathol. 52:151-165.

Roddick, J. G. 1974. The steroidal glycoalkaloid $\alpha$-tomatine. Phytochemistry 13:9-25.

Roddick, J. G. 1976. Intracellular distribution of the steroidal glycoalkaloid $\alpha$-tomatine in Lycopersicon esculentum fruit. Phytochemistry 15:475-477.

Roddick, J. G. 1977. Subcellular localization of steroidal glycoalkaloids in vegetative organs of Lycopersicon esculentum and Solanum tuberosum. Phytochemistry 16:805-807.

Roldán-Arjona, T., Pérez-Espinosa, A., and Ruiz-Rubio, M. 1999. Tomatinase from Fusarium oxysporum f. sp. lycopersici defines a new class of saponinases. Mol. Plant-Microbe Interact. 12:852-861.

Ross, I. K. 1995. Non-grinding method of DNA isolation from human pathogenic filamentous fungi using xanthogenates. Biotechniques 18:828-830.

Sambrook, J., Fritsch, E. F., and Maniatis, T. 1989. Molecular Cloning: A Laboratory Manual. Cold Spring Harbor Laboratory Press, Cold Spring Harbor, NY.

Sandrock, R. W., DellaPenna, D., and VanEtten, H. D. 1995. Purification and characterization of $\beta_{2}$-tomatinase, an enzyme involved in the degradation of $\alpha$-tomatine and isolation of the gene encoding $\beta_{2}$-tomatinase from Septoria lycopersici. Mol. Plant-Microbe Interact. 8:960-970.

Sandrock, R. W., and Van Etten, H. D. 1998. Fungal sensitivity to and enzymatic degradation of the phytoanticipin $\alpha$-tomatine. Phytopathology 88:137-143.

Schönbeck, F., and Schlösser, E. 1976. Preformed substances as potential protectants. Pages 653-678 in Physiological Plant Pathology. R. Heitefuss and P. H. Williams, eds. Springer-Verlag, Berlin.

Schulz, G., and Sander, H. 1957. Über cholesterin-Tomatid. Eine neue Molekülverbinding zur analyse und preparativen Gewinnung von Steroiden. Hoppe-Seyler's Z. Physiol. Chem. 308:122.

Senegupta, S., Prasanna, T. B., and Kasbekar, D. P. 1995. Sterol 14,15 reductase (erg-3) mutations switch the phenotype of Neurospora crassa from sensitivity to the tomato saponin $\alpha$-tomatine to sensitivity to the pea phytoalexin pisatin. Fungal Genet. Newsl. 42:71-72.

Shiriashi, T., Saitoh, K., Kim, H. M., Kato, T., Tahara, M., Oku, H., Yamada, T., and Ichinose, Y. 1992. Two suppressors, supprescins A and B, secreted by a pea pathogen, Mycosphaerella pinodes. Plant Cell Physiol. 33:663-667.

Sohi, H. S., and Sokhi, S. S. 1972. Morphological, physiological and pathological studies in Septoria lycopersici. Indian Phytopathol. 26:666-673.

Steel, C. S., and Drysdale, R. B. 1988. Electrolyte leakage from plant and fungal tissues and disruption of liposome membranes by $\alpha$ tomatine. Phytochemistry 27:1025-1030.

Suleman, P., Tohamy, A. M., Saleh, A. A., Madkour, M. A., and Straney, D. C. 1996. Variation in sensitivity to tomatine and rishitin among 
isolates of Fusarium oxysporum f. sp. lycopersici, and strains not pathogenic to tomato. Physiol. Mol. Plant Pathol. 48: 31-144.

Turner, E. M. 1961. An enzymic basis for pathogen specificity in Ophiobolus graminis. J. Exp. Bot. 12:169-175.

Urban, M., Bhargava, T., and Hamer, J. 1999. An ATP-driven efflux pump is a novel pathogenicity factor in rice blast disease. EMBO J. 18:512-521.

Urbasch, I. 1986. Transformation von $\alpha$-tomatin durch Botrytis cinerea. Planta Med. 2:114-118.

Van Kan, J. A. L., Joosten, M. H. A. J., Wagemakers, C. A. M., Van den
Berg-Velthuis, G. C. M., and De Wit, P. J. G. M. 1992. Differential accumulation of mRNAs encoding extracellular and intracellular PR proteins in tomato induced by virulent and avirulent races of $\mathrm{Cla}$ dosporium fulvum. Plant Mol. Biol. 20:513-527.

Verhoeff, K., and Liem, J. I. 1975. Toxicity of tomatine to Botrytis cinerea, in relation to latency. Phytopathol. Z. 82:333-338.

Ziegler, E., and Pontzen, R. 1982. Specific inhibition of glucan-elicited glyceollin accumulation in soybeans by an extracellular mannanprotein of Phytophthora megasperma f. sp. glycinea. Physiol. Plant Pathol. 20:321-331. 